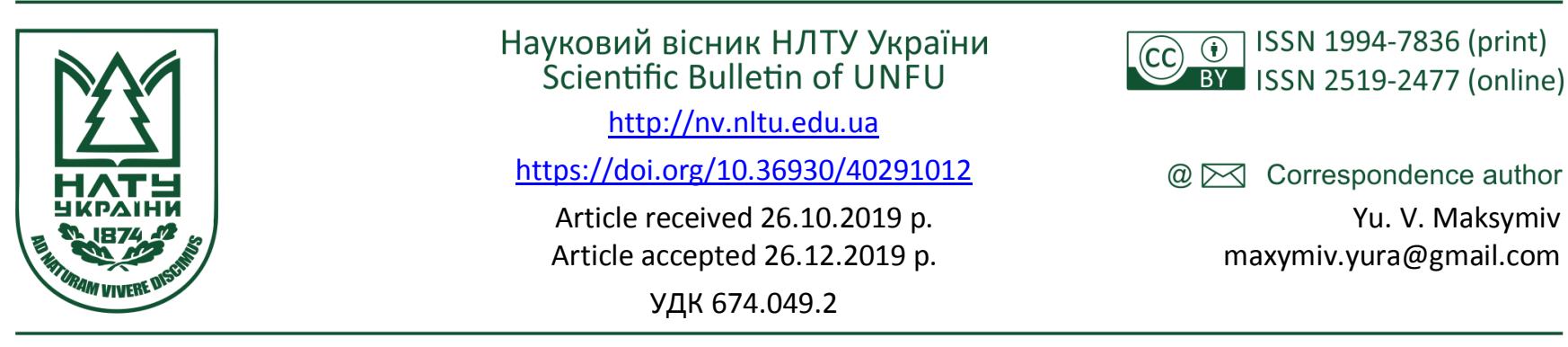

Ю. В. Максимів ${ }^{1}$, Т. Кристофяк ${ }^{2}$

${ }^{1}$ Національний лісотехнічний університет Украӥни, м. Львів, Україна

${ }^{2}$ Познанський природничий університет, м. Познань, Польщза

\title{
ВПЛИВ НАНЕСЕННЯ ЛАКОФАРБОВИХ МАТЕРІАЛІВ НА БЛИСК ТЕРМОМЕХАНІЧНО МОДИФІКОВАНОГО БЕРЕЗОВОГО (ВЕTULA VERRUCOSA) ШПОНУ
}

\begin{abstract}
Зовнішній вигляд деревини та виробів з неї є одним з ключових факторів у виборі матеріалів. Одними з основних властивостей поверхні матеріалу $є$ колір та блиск. Високий рівень блиску поверхні надає продукту більш преміального та приємного вигляду. Шпонування, як одна 3 технологій термічного модифікування, призначене для покращення деяких механічних, а також естетичних властивостей деревини, зокрема ії блиску. Нанесення лакофарбових виробів здійснюють 3 подібною метою - покращення зовнішнього вигляду поверхні та ії захист від зовнішніх впливів. Мета цього дослідження встановити динаміку зміни рівня показника блиску термомеханічно модифікованої деревини після нанесення лакового покриття та порівняння його з немодифікованою деревиною. Для цього використано шпон, виготовлений з берези способом лущення (Betula verrucosa), модифікований за температури 150, 180 та $210^{\circ} \mathrm{C}$ за допомогою контрольованого пресу ХОМко. На модифікований шпон було нанесено один або два шари лакового покриття, iз або без міжшарового шліфування. Оцінювали блиск під кутами 20,60 та 85 $а$ допомогою блискоміра Erichsen PICOGLOSS 503. Проаналізувавши результати експерименту, з'ясовано, що в разі нанесених двох шарів лаку рівень блиску вищий, ніж за одного, що міжшарове шліфування не дає відчутного ефекту на блиск поверхні лакованої термомеханічно модифікованої деревини та що вибір клею може вплинути на кінцевий показник рівня блиску.
\end{abstract}

Ключові слова: рівень блиску; шліфування; лущений шпон; вальцування.

Вступ. Одним 3 пріоритетних напрямів розвитку $є$ створення нових матеріалів, а також покращення характеристик наявних способом модифікування. У деревообробленні це стосується передусім модифікування деревини та деревинних матеріалів.

Істотних результатів у сфері термомеханічного модифікування деревини досягнуто у дослідженнях таких науковців, як П. А. Бехта, S. Proszyk, J. Sedliáčik, P. Niemz, T. Krystofiak, B. Lis та ін.

Відомо, що деревину давно і широко використовують як матеріал, якому властиві високі естетичні характеристики. Як показують дослідження, термо-механічне модифікування має істотний вплив як на деякі фізичні та механічні властивості деревини (Bekhta P., Proszyk S., Krystofiak T., Sedliáčik J., Novak I., Mamonova M.), так і на стан цілих технологічних процесів 3 погляду покращення їх ресурсоощадності та екологічності.

Зокрема, це особливо стосується процесів опорядження деревини та деревинних матеріалів, оскільки термомеханічне модифікування покращує естетичні характеристики, такі як блиск (Bekhta P., Proszyk S., Lis B., Krystofiak T.) та колір (Bekhta P., Proszyk S., Krystofiak T.) та зменшує витрати лакофарбових матеріалів.

Проте сама по собі деревина є матеріалом, який сильно піддається зовнішнім впливам. Для захисту іiі структури на поверхню деревини наносять лак, вид якого залежить від майбутнього призначення матеріалу. Лакування не тільки захищає фізичну структуру матеріалу, а й впливає на зовнішній вигляд поверхні.

Зовнішній вигляд є важливим показником оцінювання поверхні, особливо виготовленої з дерева. Під впливом температури колір змінюється (Bekhta, P., Niemz, P., Aksoy, A., Deveci, M., Baysal, E., Toker, H.;), стає темнішим, набуває червонішого відтінку.

Блиск також $є$ важливим показником зовнішнього вигляду. Aksoy (2011) виявив, що термічне модифікування знижує показник блиску поверхні сосни (Pinus Sylvestris) від 5 до 36 \%, залежно від часу та температури модифікування. Cakicier (2011) встановив, що блиск термічно модифікованої деревини за температури 150 та $180^{\circ} \mathrm{C}$, поверхня якої була покрита лаковими матеріалами, є вищим, ніж поверхня немодифікованої лакованої деревини. Якщо температура збільшувалась блиск поверхні зменшувався.

Бехта П. А., Proszyk S., Lis B. та Krystofiak T. (2014) встановили, що поверхня термомеханічно модифікованої деревини є блискучішою, ніж немодифікована. Огляд літератури показав, що на сьогодні ефект лакування на блиск поверхні термомеханічно модифікованої деревини за різних температур є недослідженим.

Матеріали та методи. Для дослідження обрано лу-

Інформація про авторів:

Максимів Юрій Володимирович, аспірант, кафедра технологій деревинних композиційних матеріалів, целюлози та паперу. Email: maxymiv.yura@gmail.com

Кристофяк Томаш, PhD, відділ клеєння та опорядження деревини. Email: tomkrys@up.poznan.pl

Цитування за ДСТУ: Максимів Ю. В., Кристофяк Т. Вплив нанесення лакофарбових матеріалів на блиск термомеханічно модифікованого березового (Betula Verrucosa) шпону. Науковий вісник НлтУ України. 2019, т. 29, № 10. С. 66-70.

Citation APA: Maksymiv, Yu. V., \& Krystofiak, T. (2019). Influence of lacquering on the gloss of thermo-mechanically modified alder veneer (Betula Verrucosa). Scientific Bulletin of UNFU, 29(10), 66-70. https://doi.org/10.36930/40291012 
щений шпон, виготовлений з породи береза (Betula verrucosa), без помітних пошкоджень, розміром $300 \times 300$ мм, товщиною 1,5 мМ, відносною вологістю $10 \%$.

Термомеханічне модифікування проводили за допомогою контрольованого пресу від компанії ХОМко. Зразки модифікували за температури 150,180 та $210{ }^{\circ} \mathrm{C}$, тиску $-2 \mathrm{MPa}$, часу -3 хв.

Після модифікування зразки було наклеєно на плити МДФ, розміром $300 \times 300 \times 16$ мм 3 використанням клеїв Jowacoll - 148.00 (етиленвінілацетатний клей) та 124.00 (полівінілацетатний клей).

Нанесення лакофарбових покриттів. Для дослідження зміни блиску термомеханічно модифікованої деревини після нанесення лакофарбових покриттів використано лак від компанії Remmers UV120-45, затверджений ультрафіолетовим опроміненням.

Лак наносили в лабораторних умовах, спосіб нанесення - вальцування, опромінення здійснювалось за допомогою обладнання від компанії MIKON, модель UVC-250x2. Шліфування контрольних взірців перед нанесенням лакового покриття та міжшарове шліфування здійснювали вручну за допомогою шліфувального паперу із зернистістю 240.

Для визначення необхідної кількості лаку кожен взірець зважували до та після нанесення лаку.

Вимірювання блиску. Блиск - здатність поверхні матеріалу відбивати світлові промені. Термо-механічне модифікування дає змогу збільшити показник відбиття світлових променів, оскільки поверхня під впливом високого тиску згладжується, що не дає матеріалу поглинати світло, вплив температури своєю чергою не дає поверхні деревини повернутися до початкового стану. Як результат, деревина стає блискучіша (табл. 1).

Вимірювання показників блиску термомеханічно модифікованої деревини проводили у два етапи: до лакування та після лакування взірців.
Табл. 1. Класифікація блиску поверхні

\begin{tabular}{|c|c|}
\hline Одиниць блиску (GU) & Оцінка \\
\hline$<10$ & Мат \\
\hline $10-35$ & Напівмат \\
\hline $35-60$ & Напівблиск \\
\hline $60-80$ & Блиск \\
\hline$>80$ & Ідеальний блиск \\
\hline
\end{tabular}

Для цього дослідження використано блискомір PICOGLOSS 503 від компанії Erichsen, відповідно до стандарту ISO 2813. Блиск поверхні немодифікованої та модифікованої без лакування та 3 нанесеним лаком вимірювали під кутом відбиття світла 20, 60 та $85^{\circ}$, вздовж $(\|)$ та впоперек $(\perp)$ волокон.

Результати дослідження. Вимірювання блиску після нанесення лакового покриття показало істотне якісне покращення властивості при усіх досліджуваних кутах відбиття світла.

Зміна блиску поверхні термомеханічно модифікованої деревини після нанесення лакового покриття становить від 43 до 9931 \% залежно від кута і кількості нанесених шарів (табл. 5-7). Температура модифікування також впливає на цей показник, але не істотно.

Як видно з табл. 2-4, нанесення двох шарів лаку має істотно більший ефект на зміну блиску, ніж нанесення одного. Також можна помітити, що міжшарове шліфування майже не впливає на показники блиску.

Найістотніші зміни відбулись у контрольних взірцях, найкраще це видно в оцінюванні під кутом відбиття $85^{\circ}$ (див. табл. 7).

Також встановлено тенденцію впливу типу клею на блиск лакованого термомеханічно модифікованого шпону. Під час нанесення одного шару лакового покриття на зразки, які були наклеєні на МДФ за допомогою полівінілацетатного клею, блиск поверхні є в 1,6 до 2,0 разів вищим, ніж у разі використання етиленвінілацетатного. Проте, в разі нанесення двох шарів лаку, цю залежність не простежували.

Табл. 2. Вплив температури модифікування на блиск поверхні під кутом відбиття світла 20

\begin{tabular}{|c|c|c|c|c|c|c|c|c|c|}
\hline \multirow{4}{*}{$\begin{array}{c}\text { Кількість шарів/ } \\
\text { міжшарове } \\
\text { шліфування }\end{array}$} & \multirow{4}{*}{ Тип клею } & \multicolumn{8}{|c|}{ Температура модифікування $\left[{ }^{\circ} \mathrm{C}\right]$} \\
\hline & & \multicolumn{2}{|c|}{ Control } & \multicolumn{2}{|c|}{150} & \multicolumn{2}{|c|}{180} & \multicolumn{2}{|c|}{210} \\
\hline & & $\|$ & $\perp$ & $\|$ & $\perp$ & $\|$ & $\perp$ & $\|$ & $\perp$ \\
\hline & & \multicolumn{8}{|c|}{ Блиск [GU] } \\
\hline- & Контроль & $\begin{array}{c}1,09 \\
(0,18)\end{array}$ & $\begin{array}{c}1,03 \\
(0,10)\end{array}$ & $\begin{array}{c}1,32 \\
(0,13)\end{array}$ & $\begin{array}{c}1,22 \\
(0,11)\end{array}$ & $\begin{array}{c}1,38 \\
(0,21)\end{array}$ & $\begin{array}{c}1,27 \\
(0,17)\end{array}$ & $\begin{array}{c}1,21 \\
(0,09)\end{array}$ & $\begin{array}{c}1,18 \\
(0,08)\end{array}$ \\
\hline \multirow{2}{*}{1} & EVA & $\begin{array}{c}1,86 \\
(1,50)\end{array}$ & $\begin{array}{c}2,26 \\
(1,64)\end{array}$ & $\begin{array}{c}5,18 \\
(1,06)\end{array}$ & $\begin{array}{c}5,66 \\
(1,20)\end{array}$ & $\begin{array}{c}3,01 \\
(1,92)\end{array}$ & $\begin{array}{c}2,89 \\
(2,67)\end{array}$ & $\begin{array}{c}3,65 \\
(0,54)\end{array}$ & $\begin{array}{c}4,94 \\
(0,77)\end{array}$ \\
\hline & PVAC & $\begin{array}{c}6,51 \\
(5,32)\end{array}$ & $\begin{array}{c}6,74 \\
(6,53)\end{array}$ & $\begin{array}{c}7,75 \\
(3,86)\end{array}$ & $\begin{array}{c}7,30 \\
(4,95)\end{array}$ & $\begin{array}{c}8,59 \\
(4,98)\end{array}$ & $\begin{array}{c}7,55 \\
(7,17)\end{array}$ & $\begin{array}{c}5,79 \\
(2,33)\end{array}$ & $\begin{array}{c}5,81 \\
(1,63)\end{array}$ \\
\hline \multirow{2}{*}{2 (без шліфування) } & EVA & $\begin{array}{l}18,41 \\
(2,48)\end{array}$ & $\begin{array}{c}16,93 \\
(1,91)\end{array}$ & $\begin{array}{l}18,54 \\
(6,69)\end{array}$ & $\begin{array}{l}20,58 \\
(6,92)\end{array}$ & $\begin{array}{l}17,25 \\
(7,71)\end{array}$ & $\begin{array}{l}17,65 \\
(5,84)\end{array}$ & $\begin{array}{c}15,79 \\
(4,58)\end{array}$ & $\begin{array}{c}17,14 \\
(3,98)\end{array}$ \\
\hline & PVAC & $\begin{array}{c}17,73 \\
(1,76)\end{array}$ & $\begin{array}{c}16,44 \\
(1,83)\end{array}$ & $\begin{array}{l}19,61 \\
(2,53)\end{array}$ & $\begin{array}{c}19,74 \\
(1,87)\end{array}$ & $\begin{array}{l}14,70 \\
(1,37)\end{array}$ & $\begin{array}{c}16,43 \\
(1,24)\end{array}$ & $\begin{array}{c}12,16 \\
(1,36)\end{array}$ & $\begin{array}{c}12,88 \\
(1,61)\end{array}$ \\
\hline \multirow{2}{*}{2 (зі шліфуванням) } & EVA & $\begin{array}{l}17,96 \\
(1,66)\end{array}$ & $\begin{array}{c}17,19 \\
(2,11)\end{array}$ & $\begin{array}{l}21,21 \\
(3,98)\end{array}$ & $\begin{array}{c}19,81 \\
(4,14)\end{array}$ & $\begin{array}{c}11,66 \\
(5,81)\end{array}$ & $\begin{array}{l}11,06 \\
(3,46)\end{array}$ & $\begin{array}{l}18,49 \\
(2,02)\end{array}$ & $\begin{array}{c}17,74 \\
(1,90)\end{array}$ \\
\hline & PVAC & $\begin{array}{c}15,85 \\
(5,95)\end{array}$ & $\begin{array}{l}13,24 \\
(2,43)\end{array}$ & $\begin{array}{c}18,95 \\
(3,82) \\
\end{array}$ & $\begin{array}{c}21,05 \\
(2,08)\end{array}$ & $\begin{array}{c}19,14 \\
(1,90)\end{array}$ & $\begin{array}{c}17,39 \\
(2,12) \\
\end{array}$ & $\begin{array}{r}19,48 \\
(5,62) \\
\end{array}$ & $\begin{array}{r}18,60 \\
(4,38) \\
\end{array}$ \\
\hline
\end{tabular}

Табл. 3. Вплив температури модифікування на блиск поверхні під кутом відбиття світла 60

\begin{tabular}{|c|c|c|c|c|c|c|c|c|c|}
\hline \multirow{4}{*}{$\begin{array}{c}\text { Кількість ша- } \\
\text { рів/міжшарове } \\
\text { шліфування }\end{array}$} & \multirow{4}{*}{ Тип клею } & \multicolumn{8}{|c|}{ Температура модифікування [ $\left.{ }^{\circ} \mathrm{C}\right]$} \\
\hline & & \multicolumn{2}{|c|}{ control } & \multicolumn{2}{|c|}{150} & \multicolumn{2}{|c|}{180} & \multicolumn{2}{|c|}{210} \\
\hline & & $\|$ & $\perp$ & $\|$ & $\perp$ & $\|$ & $\perp$ & $\|$ & $\perp$ \\
\hline & & \multicolumn{8}{|c|}{ Блиск [GU] } \\
\hline- & Контроль & $\begin{array}{c}3,72 \\
(1,01)\end{array}$ & $\begin{array}{c}2,62 \\
(0,37)\end{array}$ & $\begin{array}{c}6,52 \\
(0,80)\end{array}$ & $\begin{array}{c}4,67 \\
(0,48)\end{array}$ & $\begin{array}{c}6,43 \\
(0,66)\end{array}$ & $\begin{array}{c}4,60 \\
(0,18)\end{array}$ & $\begin{array}{c}6,29 \\
(0,87)\end{array}$ & $\begin{array}{c}4,80 \\
(0,55)\end{array}$ \\
\hline
\end{tabular}




\begin{tabular}{|c|c|c|c|c|c|c|c|c|c|}
\hline \multirow{2}{*}{1} & EVA & $\begin{array}{r}32,08 \\
(6,03)\end{array}$ & $\begin{array}{l}32,01 \\
(6,12)\end{array}$ & $\begin{array}{l}23,05 \\
(7,20)\end{array}$ & $\begin{array}{c}19,08 \\
(7,28)\end{array}$ & $\begin{array}{l}23,50 \\
(9,69)\end{array}$ & $\begin{array}{c}25,85 \\
(13,14)\end{array}$ & $\begin{array}{l}15,00 \\
(4,29)\end{array}$ & $\begin{array}{l}15,36 \\
(5,43)\end{array}$ \\
\hline & PVAC & $\begin{array}{l}43,28 \\
(6,58)\end{array}$ & $\begin{array}{c}39,86 \\
(10,39)\end{array}$ & $\begin{array}{l}45,45 \\
(4,48)\end{array}$ & $\begin{array}{l}40,14 \\
(9,78)\end{array}$ & $\begin{array}{c}34,75 \\
(7,37)\end{array}$ & $\begin{array}{c}34,73 \\
(14,67)\end{array}$ & $\begin{array}{c}37,39 \\
(2,7)\end{array}$ & $\begin{array}{l}35,84 \\
(3,33)\end{array}$ \\
\hline \multirow{2}{*}{2 (без шліфування) } & EVA & $\begin{array}{r}62,40 \\
(2,89) \\
\end{array}$ & $\begin{array}{l}61,58 \\
(2,27)\end{array}$ & $\begin{array}{c}62,48 \\
(14,27)\end{array}$ & $\begin{array}{c}58,04 \\
(20,97) \\
\end{array}$ & $\begin{array}{l}59,58 \\
(8,44)\end{array}$ & $\begin{array}{c}55,08 \\
(14,63)\end{array}$ & $\begin{array}{r}61,59 \\
(4,16) \\
\end{array}$ & $\begin{array}{l}58,38 \\
(8,19) \\
\end{array}$ \\
\hline & PVAC & $\begin{array}{l}64,60 \\
(5,10)\end{array}$ & $\begin{array}{l}63,36 \\
(4,17)\end{array}$ & $\begin{array}{l}56,90 \\
(5,58)\end{array}$ & $\begin{array}{l}57,54 \\
(5,68)\end{array}$ & $\begin{array}{l}52,26 \\
(4,36)\end{array}$ & $\begin{array}{l}51,26 \\
(3,98)\end{array}$ & $\begin{array}{l}60,23 \\
(6,11)\end{array}$ & $\begin{array}{l}57,16 \\
(6,36)\end{array}$ \\
\hline \multirow{2}{*}{2 (зі шліфуванням) } & EVA & $\begin{array}{r}64,34 \\
(0,51)\end{array}$ & $\begin{array}{c}62,43 \\
(1,88)\end{array}$ & $\begin{array}{l}51,35 \\
(9,04)\end{array}$ & $\begin{array}{l}40,81 \\
(7,82)\end{array}$ & $\begin{array}{c}62,69 \\
(11,12)\end{array}$ & $\begin{array}{c}59,01 \\
(8,81)\end{array}$ & $\begin{array}{l}63,15 \\
(2,67)\end{array}$ & $\begin{array}{l}57,81 \\
(3,56)\end{array}$ \\
\hline & PVAC & $\begin{array}{r}59,83 \\
(9,21)\end{array}$ & $\begin{array}{l}63,35 \\
(4,11)\end{array}$ & $\begin{array}{l}61,65 \\
(4,41)\end{array}$ & $\begin{array}{l}59,39 \\
(3,10)\end{array}$ & $\begin{array}{l}64,26 \\
(2,37)\end{array}$ & $\begin{array}{l}62,09 \\
(2,74)\end{array}$ & $\begin{array}{l}59,68 \\
(9,01)\end{array}$ & $\begin{array}{c}49,55 \\
(12,30)\end{array}$ \\
\hline
\end{tabular}

Табл. 4. Вплив температури модифікування на блиск поверхні під кутом відбиття світла $85^{\circ}$

\begin{tabular}{|c|c|c|c|c|c|c|c|c|c|}
\hline \multirow{4}{*}{$\begin{array}{c}\text { Кількість } \\
\text { шарів/міжшарове } \\
\text { шліфування }\end{array}$} & \multirow{4}{*}{ Тип клею } & \multicolumn{8}{|c|}{ Температура модифікування $\left[{ }^{\circ} \mathrm{C}\right]$} \\
\hline & & \multicolumn{2}{|c|}{ control } & \multicolumn{2}{|c|}{150} & \multicolumn{2}{|c|}{180} & \multicolumn{2}{|c|}{210} \\
\hline & & $\|$ & $\perp$ & $\|$ & $\perp$ & $\|$ & $\perp$ & $\|$ & $\perp$ \\
\hline & & \multicolumn{8}{|c|}{ Блиск [GU] } \\
\hline- & Контроль & $\begin{array}{c}1,84 \\
(0,99)\end{array}$ & $\begin{array}{c}1,17 \\
(0,27) \\
\end{array}$ & $\begin{array}{l}13,99 \\
(2,50)\end{array}$ & $\begin{array}{l}11,83 \\
(2,14)\end{array}$ & $\begin{array}{c}12,62 \\
(2,69)\end{array}$ & $\begin{array}{c}10,66 \\
(3,27)\end{array}$ & $\begin{array}{c}15,11 \\
(1,53)\end{array}$ & $\begin{array}{c}13,34 \\
(1,6)\end{array}$ \\
\hline \multirow{2}{*}{1} & EVA & $\begin{array}{c}65,35 \\
(10,19)\end{array}$ & $\begin{array}{c}65,93 \\
(13,13)\end{array}$ & $\begin{array}{c}51,71 \\
(13,99)\end{array}$ & $\begin{array}{c}35,78 \\
(14,06)\end{array}$ & $\begin{array}{c}60,70 \\
(22,48)\end{array}$ & $\begin{array}{c}54,96 \\
(22,86)\end{array}$ & $\begin{array}{c}41,80 \\
(11,17)\end{array}$ & $\begin{array}{r}31,00 \\
(15,09)\end{array}$ \\
\hline & PVAC & $\begin{array}{c}72,21 \\
(8,9)\end{array}$ & $\begin{array}{c}63,55 \\
(14,06)\end{array}$ & $\begin{array}{c}74,21 \\
(6,16)\end{array}$ & $\begin{array}{c}67,84 \\
(11,69)\end{array}$ & $\begin{array}{l}71,26 \\
(9,06)\end{array}$ & $\begin{array}{c}73,26 \\
(21,04)\end{array}$ & $\begin{array}{c}77,93 \\
(4,43)\end{array}$ & $\begin{array}{c}73,65 \\
(9,39)\end{array}$ \\
\hline \multirow{2}{*}{2 (без шліфування) } & EVA & $\begin{array}{l}81,31 \\
(1,95)\end{array}$ & $\begin{array}{c}79,04 \\
(3,2)\end{array}$ & $\begin{array}{c}84,59 \\
(16,96)\end{array}$ & $\begin{array}{c}81,94 \\
(29,52)\end{array}$ & $\begin{array}{l}81,90 \\
(9,32)\end{array}$ & $\begin{array}{c}76,53 \\
(19,21)\end{array}$ & $\begin{array}{l}89,96 \\
(6,95)\end{array}$ & $\begin{array}{c}86,99 \\
(14,73)\end{array}$ \\
\hline & PVAC & $\begin{array}{c}89,75 \\
(11,37)\end{array}$ & $\begin{array}{c}88,61 \\
(10,55)\end{array}$ & $\begin{array}{c}81,85 \\
(5,86)\end{array}$ & $\begin{array}{c}87,51 \\
(11,10)\end{array}$ & $\begin{array}{c}75,69 \\
(10,24)\end{array}$ & $\begin{array}{c}73,96 \\
(7,9)\end{array}$ & $\begin{array}{l}89,51 \\
(5,65)\end{array}$ & $\begin{array}{c}87,24 \\
(14,76)\end{array}$ \\
\hline \multirow{2}{*}{2 (зі шліфуванням) } & EVA & $\begin{array}{l}90,58 \\
(2,79)\end{array}$ & $\begin{array}{l}88,28 \\
(5,22) \\
\end{array}$ & $\begin{array}{c}72,68 \\
(7,92) \\
\end{array}$ & $\begin{array}{c}52,98 \\
(6,67)\end{array}$ & $\begin{array}{c}84,93 \\
(12,49) \\
\end{array}$ & $\begin{array}{c}77,14 \\
(14,64) \\
\end{array}$ & $\begin{array}{c}85,03 \\
(5,9) \\
\end{array}$ & $\begin{array}{c}77,84 \\
(10,29) \\
\end{array}$ \\
\hline & PVAC & $\begin{array}{l}88,13 \\
(7,26)\end{array}$ & $\begin{array}{l}88,04 \\
(5,12)\end{array}$ & $\begin{array}{l}89,30 \\
(2,81)\end{array}$ & $\begin{array}{l}87,78 \\
(4,02)\end{array}$ & $\begin{array}{l}87,73 \\
(2,65)\end{array}$ & $\begin{array}{l}85,85 \\
(2,66)\end{array}$ & $\begin{array}{c}80,10 \\
(10,85)\end{array}$ & $\begin{array}{c}64,58 \\
(15,94)\end{array}$ \\
\hline
\end{tabular}

Табл. 5. Абсолютна та відносна різниця зміни блиску поверхні під кутом $20^{\circ}$ після нанесення лакового покриття

\begin{tabular}{|c|c|c|c|c|c|c|c|c|c|c|}
\hline \multirow{2}{*}{$\begin{array}{c}\text { Кількість ша- } \\
\text { рів/міжшарове } \\
\text { шліфування }\end{array}$} & \multirow{2}{*}{$\begin{array}{c}\text { Тип } \\
\text { клею }\end{array}$} & \multirow[b]{2}{*}{ Зміна } & \multicolumn{2}{|c|}{ Контрольні } & \multicolumn{2}{|c|}{150} & \multicolumn{2}{|c|}{180} & \multicolumn{2}{|c|}{210} \\
\hline & & & $\|$ & $\perp$ & $\|$ & $\perp$ & $\|$ & $\perp$ & $\|$ & $\perp$ \\
\hline \multirow[t]{4}{*}{$x_{10}$} & \multirow{2}{*}{ EVA } & Абс. & 4,18 & 4,62 & 1,93 & 1,85 & 2,07 & 3,54 & 0,56 & 1,02 \\
\hline & & Відн. & 417,50 & 444,47 & 178,94 & 177,64 & 131,01 & 252,68 & 43,27 & 82,46 \\
\hline & \multirow{2}{*}{ PVAC } & Абс. & 6,79 & 6,36 & 7,29 & 6,39 & 4,31 & 4,49 & 5,43 & 5,62 \\
\hline & & Відн. & 707,29 & 676,60 & 560,58 & 550,86 & 291,05 & 340,34 & 503,01 & 501,56 \\
\hline \multirow{4}{*}{2 (без шліф.) } & \multirow{2}{*}{ EVA } & Абс. & 17,48 & 19,56 & 15,91 & 16,35 & 14,69 & 16,08 & 17,11 & 15,63 \\
\hline & & Відн. & 1648,82 & 1917,16 & 1187,31 & 1257,69 & 1335,23 & 1516,75 & 1316,35 & 1201,92 \\
\hline & \multirow{2}{*}{ PVAC } & Абс. & 18,27 & 18,58 & 13,28 & 15,11 & 10,62 & 11,50 & 16,59 & 15,28 \\
\hline & & Відн. & 1363,62 & 1601,51 & 935,21 & 1144,32 & 689,77 & 832,97 & 1454,82 & 1317,03 \\
\hline \multirow{4}{*}{2 (зі шліф.) } & \multirow{2}{*}{ EVA } & Абс. & 20,31 & 18,91 & 10,20 & 9,74 & 17,37 & 16,68 & 16,72 & 16,09 \\
\hline & & Відн. & 2256,94 & 2101,39 & 698,80 & 738,07 & 1550,67 & 1573,35 & 1348,59 & 1462,50 \\
\hline & \multirow{2}{*}{ PVAC } & Абс. & 17,69 & 19,95 & 17,84 & 16,19 & 18,02 & 17,20 & 14,67 & 12,10 \\
\hline & & Відн. & 1403,97 & 1813,64 & 1372,12 & 1348,96 & 1233,90 & 1228,57 & 1243,22 & 1061,18 \\
\hline
\end{tabular}

Табл. 6. Абсолютна та відносна різниця зміни блиску поверхні під кутом 60ㅜ після нанесення лакового покриття

\begin{tabular}{|c|c|c|c|c|c|c|c|c|c|c|}
\hline \multirow{2}{*}{$\begin{array}{c}\text { Кількість ша- } \\
\text { рів/міжшарове } \\
\text { шліфування }\end{array}$} & \multirow{2}{*}{$\begin{array}{c}\text { Тип } \\
\text { клею }\end{array}$} & \multirow[b]{2}{*}{ Зміна } & \multicolumn{2}{|c|}{ Контрольні } & \multicolumn{2}{|c|}{150} & \multicolumn{2}{|c|}{180} & \multicolumn{2}{|c|}{210} \\
\hline & & & $\|$ & $\perp$ & $\|$ & $\perp$ & $\|$ & $\perp$ & $\|$ & $\perp$ \\
\hline \multirow{4}{*}{1} & \multirow{2}{*}{ EVA } & Абс. & 29,10 & 29,55 & 17,67 & 15,26 & 16,52 & 21,25 & 7,66 & 10,26 \\
\hline & & Відн. & 976,34 & 1201,32 & 328,44 & 399,35 & 236,68 & 461,96 & 104,36 & 201,23 \\
\hline & \multirow{2}{*}{ PVAC } & Абс. & 40,16 & 37,44 & 38,65 & 35,44 & 27,83 & 30,07 & 32,25 & 31,70 \\
\hline & & Відн. & 1287,02 & 1547,21 & 568,38 & 753,99 & 402,17 & 645,17 & 627,38 & 765,64 \\
\hline \multirow{4}{*}{2 (без шліф.) } & \multirow{2}{*}{ EVA } & Абс. & 59,04 & 59,16 & 56,10 & 53,22 & 54,06 & 50,76 & 54,35 & 52,86 \\
\hline & & Відн. & 1757,14 & 2444,42 & 879,23 & 1104,10 & 979,26 & 1174,88 & 750,66 & 957,52 \\
\hline & \multirow{2}{*}{ PVAC } & Абс. & 59,42 & 60,22 & 49,18 & 52,48 & 45,16 & 46,78 & 54,55 & 52,22 \\
\hline & & Відн. & 1147,10 & 1917,91 & 637,05 & 1037,10 & 636,09 & 1044,25 & 960,30 & 1057,14 \\
\hline \multirow{4}{*}{2 (зі шліф.) } & \multirow{2}{*}{ EVA } & Абс. & 61,48 & 60,19 & 44,55 & 36,33 & 56,79 & 54,21 & 56,85 & 53,67 \\
\hline & & Відн. & 2149,56 & 2686,83 & 655,15 & 810,99 & 962,50 & 1129,43 & 902,38 & 1296,44 \\
\hline & \multirow{2}{*}{ PVAC } & Абс. & 55,03 & 60,31 & 55,63 & 54,25 & 58,08 & 57,35 & 53,64 & 44,57 \\
\hline & & Відн. & 1146,35 & 1983,88 & 924,09 & 1055,40 & 939,85 & 1209,86 & 888,00 & 894,98 \\
\hline
\end{tabular}


Табл. 7. Абсолютна та відносна різниця зміни блиску поверхні під кутом $85^{\circ}$ після нанесення лакового покриття

\begin{tabular}{|c|c|c|c|c|c|c|c|c|c|c|}
\hline \multirow{2}{*}{$\begin{array}{c}\text { Кількість ша- } \\
\text { рів/міжшарове } \\
\text { шліфування }\end{array}$} & \multirow{2}{*}{$\begin{array}{c}\text { Тип } \\
\text { клею }\end{array}$} & \multirow[b]{2}{*}{ Зміна } & \multicolumn{2}{|c|}{ Контрольні } & \multicolumn{2}{|c|}{150} & \multicolumn{2}{|c|}{180} & \multicolumn{2}{|c|}{210} \\
\hline & & & $\|$ & $\perp$ & $\|$ & $\perp$ & $\|$ & $\perp$ & $\|$ & $\perp$ \\
\hline \multirow{4}{*}{1} & \multirow{2}{*}{ EVA } & Абс. & 64,11 & 64,79 & 37,55 & 23,88 & 51,82 & 47,78 & 24,68 & 16,90 \\
\hline & & Відн. & 5170,16 & 5682,89 & 265,20 & 200,63 & 583,56 & 665,49 & 144,16 & 119,86 \\
\hline & \multirow{2}{*}{ PVAC } & Абс. & 71,03 & 62,63 & 58,57 & 56,88 & 58,36 & 63,80 & 65,39 & 62,33 \\
\hline & & Відн. & 6019,70 & 6807,61 & 374,50 & 518,96 & 452,42 & 674,45 & 521,41 & 550,62 \\
\hline \multirow{4}{*}{2 (без шліф.) } & \multirow{2}{*}{ EVA } & Абс. & 79,85 & 77,96 & 71,39 & 67,18 & 67,28 & 63,31 & 74,18 & 73,07 \\
\hline & & Відн. & 5469,35 & 7218,29 & 540,81 & 455,13 & 460,19 & 478,86 & 470,10 & 524,91 \\
\hline & \multirow{2}{*}{ PVAC } & Абс. & 86,35 & 87,03 & 64,11 & 76,55 & 63,59 & 65,42 & 74,49 & 73,96 \\
\hline & & Відн. & 2539,71 & 5508,39 & 361,39 & 698,47 & 525,52 & 766,07 & 495,96 & 556,91 \\
\hline \multirow{4}{*}{2 (3 шліф.) } & \multirow{2}{*}{ EVA } & Абс. & 89,58 & 87,40 & 62,16 & 44,24 & 68,49 & 61,22 & 69,39 & 66,06 \\
\hline & & Відн. & 8957,50 & 9931,25 & 590,83 & 506,12 & 416,58 & 384,53 & 443,64 & 560,76 \\
\hline & \multirow{2}{*}{ PVAC } & Абс. & 85,37 & 86,64 & 76,62 & 74,12 & 76,95 & 76,21 & 65,54 & 48,94 \\
\hline & & Відн. & 3092,93 & 6188,39 & 604,26 & 542,57 & 713,78 & 790,56 & 450,14 & 312,88 \\
\hline
\end{tabular}

\section{Висновки:}

1) Результати дослідження показали, що поверхня немодифікованого та модифікованого березового шпону є матовою.

2) Нанесення лаку на поверхню істотно підвищує показник блиску. Оцінка блиску поверхні під кутом відбиття світла $20^{\circ}$ змінюється 3 матової до напівматової, під кутом $60^{\circ}$ - до напівблискучої, під кутом $85^{\circ}$ поверхня стала блискучою або з ідеальним блиском. Нанесення двох шарів лаку, а не одного, також позитивно впливає на кінцевий результат. Температура термомеханічного ущільнення шпону неістотно впливає на показники блиску модифікованої деревини.

3) Зразки шпону з одним шаром лакового покриття, наклеєні на МДФ за допомогою клею PVAC, мають вищі показники блиску, ніж за допомогою EVA. Якщо кількість шарів лаку збільшувалась до двох, цю тенденцію не простежували.

\section{References}

Akgul, M., \& Korkut, S. (2012). The effect of heat treatment on some chemical properties and colour in Scots pine and Uludag fir wood. African Journal of Biotechnology, 7(21), 2854-2859.

Aksoy, A., Deveci, M., Baysal, E., \& Toker, H. (2011). Colour and gloss changes of Scots pine after heat modification. Wood Research, 56(3), 329-336.

Anonymous. (2003). Przemysłowe lakierowanie powierzchni drzewnych. Katalog firmy Akzo Nobel, (pp. 1-23).

Bakar, F. B., Hiziroglu S., \& Tahir P. (2013). Properties of some thermally modified wood species. Materials and Design, 43, 348-355.

Bekhta, P., \& Niemz, P. (2003). Effect of high temperature on the changes in colour, dimensional stability and mechanical properties of spruce wood. Holzforschung, 57(5), 539-546.

Bekhta, P., Proszyk, S., \& Krystofiak, T. (2014). Colour in short-term thermo-mechanically densified veneer of various wood species. $E u$ ropean Journal of Wood and Wood Products, 72(6), 785-797.

Bekhta, P., Proszyk, S., Krystofiak, T., Sedliáčik, J., Novak, I., \& Mamonova, M. (2015b). Effects of short-term thermo mechanical den- sification on the structure and properties of wood veneers. Wood Material Science \& Engineering, 1-15.

Bekhta, P., Proszyk, S., Lis, B., \& Krystofiak, T. (2014). Gloss of thermally densified alder (Alnus glutinosa Goertn.), beech (Fagus sylvatica L.), birch (Betula verrucosa Ehrh.), and pine (Pinus sylvestris L.) wood veneers. European Journal of Wood and Wood Products, 72(6), 799-808.

Budakci, M., Ozcifci, A., Cinar, H., \& Sonmez, A. (2009). Effects of application methods and species of wood on color changes of varnishes. African Journal of Biotechnology, 8(21), 5964-5970.

Cakicier, N., Korkut, S., Korkut, D. S., Kurtoglu, A., \& Sonmez, A. (2011). Effects of QUV accelerated aging on surface hardness, surface roughness, glossiness, and color difference for some wood species. Int J Phys Sci, 6(8), 1929-1939.

Hill, C. (2006). Wood modification - chemical, thermal and other processes. Chichester: John Wiley \& Sons Ltd., pp. 1-239.

Korkut, D. S., \& Guller, B. (2008). The effects of heat treatment on physical properties and surface roughness of red-bud maple (Acer trautvetteri Medw.) wood. Bioresource Technology, 99, 28462851.

Lis, B., Krystofiak, T., Proszyk, S., Bekhta, P., Wojkiewicz, B., \& Muszyńska, M. (2016). Investigations of the colour and gloss degree of TM densification beech veneers and finished with acrylic lacquer coatings. Investigations of the colour and gloss of TM densified beech veneers finished with acrylic lacquer. Implementation of wood science in woodworking sector: $27^{\text {th }}$ International Conference on Wood Science and Technology (ICWST), (pp. 143-151). Zagreb, Croatia, October 13-14.

Poncsak, S., Kocaefe, D., Bouazara, M., \& Pichette, A. (2006). Effect of high temperature treatment on the mechanical properties of birch. Wood Science Technology, 40, 647-668.

Safin, R. G., Khasanshin, R. R., Shaikhutdinova, A. R., \& Safina, A. V. (2014). Research of heating rate while thermo modification of wood. World Applied Sciences Journal, 30(11), 1618-1621.

Salca, E. A., \& Hiziroglu, S. (2014). Evaluation of hardness and surface quality of different wood species as function of heat treatment. Materials and Design, 62, 416-423.

Todorovic, N. V., Popović, Z., Milić, G., \& Popadić, R. (2012). Estimation of heat-treated beechwood properties by color change. $B i-$ oResources, 7(1), 0799-0815.

Yu. V. Maksymivi, T. Krystofiak ${ }^{2}$

${ }^{I}$ Ukrainian National Forestry University, Lviv, Ukraine ${ }^{2}$ Poznan University of Life Sciences, Poznan, Poland

\section{INFLUENCE OF LACQUERING ON THE GLOSS OF THERMO-MECHANICALLY MODIFIED ALDER VENEER (BETULA VERRUCOSA)}

The appearance of wood and wood products is one of the key factors in the selection of materials. Color and gloss of the surface of the material are key factors of appearance. By gloss we understand the ability of the surface to reflect light. High level of surface gloss gives to the product a more premium and attractive look. Wood as material is strongly vulnerable to external influence and has the ability to return to previous original state after modification. Thermo-mechanical modification of wood is provided in order to improve aesthetic, protective and mechanical properties of wood, in particular, to increase the level of gloss. Under the influence of 
high pressure, surface becomes smoother which prevents the material from absorbing light. One the effects of high temperature is preventing wood from returning to original state. Application of lacquer is carried out with the same purpose, i.e. to improve the appearance of the surface and its protection against external influences. The main goal of this study was to determine the dynamics of the gloss level index of thermo mechanically modified wood after lacquering and comparing result with non-modified lacquered wood. For this purpose, we used veneer sheets made from birch wood (Betula verrucosa) by peeling, modified at temperatures of $150^{\circ}$ $\mathrm{C}, 180^{\circ} \mathrm{C}$ and $210^{\circ} \mathrm{C}$ using a controlled press made by HOMco company. One or two layers of lacquer coating hardened with ultraviolet radiation, with or without interlayer grinding, were applied on the modified veneer. A gloss level was measured at 20", 60", and 85" angles with Erichsen PICOGLOSS 503 glossmeter. The analysis of the results of the experiment has shown that after lacquering gloss level becomes significantly higher at all angles of reflection. Depending on the angle of reflection and number of layers, a gloss level can rise up from 43 percent up to $9931 \%$. Applying two layers of lacquer gives higher level of gloss than applying only one layer. The results have also shown that the interlayer sanding and temperature of modification have a little effect on the gloss of surface of lacquered thermo-mechanically modified wood and that the choice of glue can affect the final level of gloss.

Keywords: gloss level; sanding; peeled veneer; rolling. 